\title{
CAVE BEAR, CAVE LION AND CAVE HYENA SKULLS FROM THE PUBLIC COLLECTION AT THE HUMBOLDT MUSEUM IN BERLIN
}

\author{
LOBANJE JAMSKEGA MEDVEDA, JAMSKEGA LEVA IN JAMSKE \\ HIJENE IZ ZBIRKE HUMBOLDTOVEGA MUZEJA V BERLINU
}

\author{
Stephan KEMPE ${ }^{1} \&$ Doris DÖPPES $^{2}$
}

\begin{abstract}
UDC 569(069.5)(430 Berlin)

069.02:569(430 Berlin)

Stephan Kempe and Doris Döppes: Cave bear, cave lion and cave hyena skulls from the public collection at the Humboldt Museum in Berlin

The Linnean binomial system rests on the description of a holotype. The first fossil vertebrate species named accordingly was Ursus spelaeus, the cave bear. It was described by Rosenmüller in 1794 in his dissertation using a skull from the Zoolithen Cave (Gailenreuth Cave) in Frankonia, Germany. The whereabouts of this skull is unknown. In the Humboldt Museum, Berlin, historic skulls of the three "spelaeus species" (cave bear, cave lion, cave hyena) are displayed. We were allowed to investigate them and further material in the Museum's archive in an attempt to locate the holotype skull. Here we report about our findings giving pertinent measurements of this historic material and depicting it for the first time. Studying the old labels we were able to establish the provenience of much of the material that includes in fact specimens from the original Rosenmüller collection. One of the cave lion skulls may actually be the one used in establishing the cave lion by Goldfuß (Diedrich 2008) while another may be the original that was used to define a "cave wolf".

Keywords: holotypes, cave bear, cave lion, cave hyena, Zoolithen Cave, Rösenbeck Cave, Humboldt Museum, Berlin.
\end{abstract}

Izvleček

069.02:569(430 Berlin)

Stephan Kempe and Doris Döppes: Lobanje jamskega medveda, jamskega leva in jamske hijene iz zbirke Humboldtovega muzeja v Berlinu

Linnejev binomski sistem poimenovanja temelji na opisu holotipa. Jamski medved je bil prva vrsta fosilnih vretenčarjev zapisana v tem sistemu. V svoji disertaciji ga je opisal Rosenmüller leta 1794, pri čemer je uporabil okostje iz jame Zoolithen (Gailenreuthska jama) v Frankoniji. Okoliščine oziroma usoda tega skeleta je neznana. Humboldtov muzej v Berlinu hrani tri fosilne vrste jamskih vretenčarjev: jamskega medveda, hijeno in jamskega leva. Omogočeno nam je bilo raziskovanje teh okostij in ostalega arhivskega gradiva, pri čemer je bil naš namen odkriti lobanjo holotipa. $V$ članku poročamo o naših izsledkih in prvi predstavimo ustrezne meritve tega zgodovinskega gradiva. Študija oznak gradiva, med katerimi so tudi primerki Rosennmüllerjeve zbirke, nam je omogočila določitev njegovega izvora. Enega od jamskih levov je pri vpeljavi verjetno uporabil Goldfuß (Diedrich 2008), medtem ko je bil nek drug primerek verjetno vzorčni primer pri definiciji »jamskega volka«.

Ključne besede: holotipi, jamski medved, jamski lev, jamska hijena, Humboldtov muzej, Berlin.

\section{INTRODUCTION}

Karst depressions and caves were the sources for most of the important early discoveries of extinct Pleistocene animals. At first mined for medical purposes as unicornu fossile and attributed to either the unicorn or to dragons (e.g., Nielbock 2004; Paterson Hain 1673a, b; Vollgnad 1676), the bones started to attract paleontological interest only in the second half of the $18^{\text {th }}$ century. Productive caves were the Baumann's and the Unicorn Caves in the

${ }^{1}$ Prof. Dr. Stephan Kempe, Institute for Applied Geosciences, University of Technology Darmstadt, Schnittspahnstr. 9, D-64287 Darmstadt, e-mail: kempe@geo.tu-darmstadt.de

${ }^{2}$ Dr. Doris Döppes, Biologische Station Lunz am See, Austrian Academy of Sciences \& Institute of Palaeontology, University of Vienna, Althanstr. 14, A-1090 Vienna, e-mail: doris.doeppes@univie.ac.at

Received/Prejeto: 05.01.2009 
Harz, several caves in the northern Rhenish Massive, in Franconia the Zoolithen Cave and the caves in the Carpathian Mountains. Horst (1656), in a single sentence, was the first to acknowledge the possible sources of the cave bones from the Unicorn Cave when he wrote: Juxta sylvam Semanam at radicem Arcis Brunsuicensis Scharzfeld vidi erui ossa, dentis, mandibulas varias, ursarum, leonum, hominum \& aliorum animatium emulas ${ }^{3}$. Paterson Hain, even though a medical doctor, did not follow this insight and classified his cave bear material as "Draco". At least he was the first to publish exact figures of the enigmatic fossils. Almost 100 years later, still another physician, Johann Friedrich Zückert, visiting the Baumann's Cave (Zückert 1763; Kempe et al. 1999) failed to identify the cave bones correctly. Johann Friedrich Esper's seminal folio about the bones from the Zoolithen Cave near Gailenreuth (Esper 1774) was a breakthrough in as much as he removed any doubt that the bones belonged to animals like bears. Lacking comparative material he

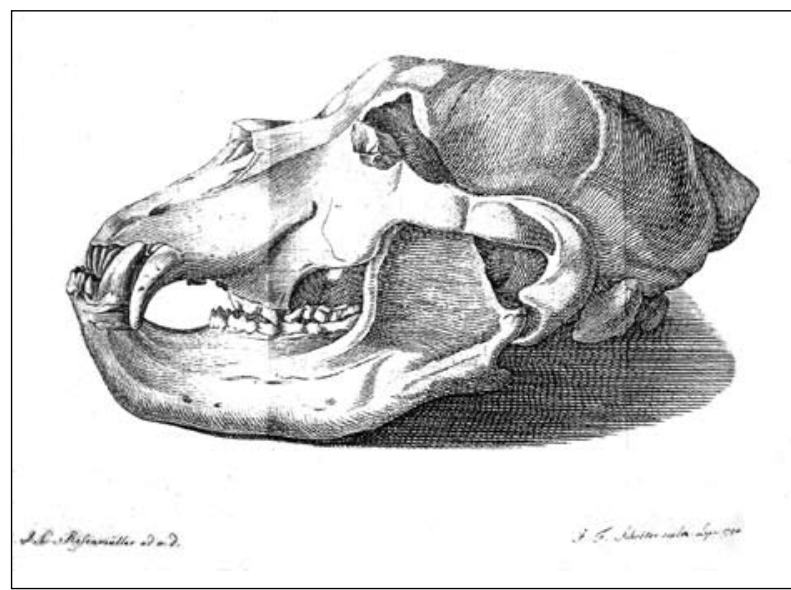

Fig. 1: Complete skull of Ursus spelaeus (holotype), copperplate of Rosenmüller, 1794 (Photo: S. Kempe).

assumed the bones to derive from polar bears, washed into Franconian caves by the Deluge. In parallel, Carl von Linné (1707-1778) introduced the concept of the species and established the binominal nomenclature for animals, plants and even rocks (Linné 1758). The concept was eagerly taken up by natural scientists in Scandinavia and Central Europe, but not so quickly by French and British researchers. This is probably the reason why most of the large extinct Pleistocene animals were named

\footnotetext{
${ }^{3}$ Translation by S. Kempe, Darmstadt, and F. Reinboth, Braunschweig: Near the Semanish Forest (i.e. the Harz Mountains), at the foot of the Brunswick Castle Scharzfeld I saw how bones, teeth, various mandibles, that emulated those of bears, lions, humans and other living beings, were excavated (Kempe et al. 2005).
}

by Central European scientists. The first was the physician Johann Christian Rosenmüller (1771-1820), who, in his doctoral thesis, presented a complete bear skull of the Zoolithen Cave (Fig. 1) and named it Ursus spelaeus in 1794 (Rosenmüller 1794, 1795; Rosendahl \& Kempe 2004). Later he also published the post-cranial bones of the cave bear (Rosenmüller 1804). Erdbrink (1953) and Kempe et al. (2005) reviewed the literature leading towards this scientific breakthrough that accepted fossil species into the scientific nomenclature. Soon after, the mammoth (Mammuthus primigenius, BLUMENBACH, 1799) and the woolly rhinoceros (Coelodonta antiquitatis, BLUMENBACH, 1799) were named by Johann Friedrich Blumenbach (1752-1840) (Blumenbach 1799) using material from gypsum karst "Schlotten" among others from the Hainholz near Osterode/South Harz (Vladi 1979). Finally Georg August Goldfuß, again using material from the Zoolithen Cave named the cave lion (Panthera leo spelaea, GOLDFUSS, 1810) (Felis spelaea

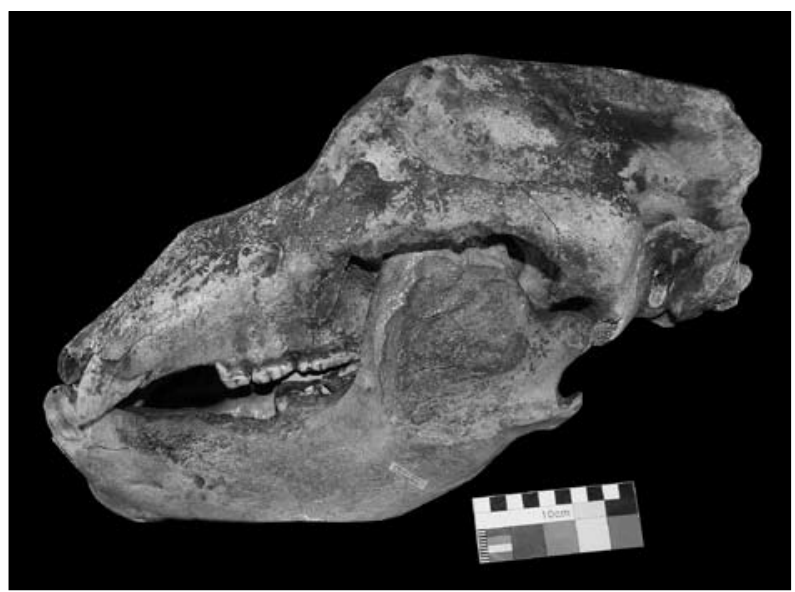

Fig. 2: Mounted cave bear skull with the label showing its provenience from L'Herm (Ariége, France), Collection Marty (public collection at the Humboldt Museum). It is normally displayed from the right side (Photo: $S$. Kempe).

by Goldfuß 1810) and the cave hyena (Crocuta crocuta spelaea, GOLDFUSS, 1823) (Hyaena spelaea by Goldfuß 1823). He even tried to establish Canis spelaeus (Goldfuß 1823) and Gulo spelaeus (Goldfuß 1818). Both species were, however, not accepted as separate species as more comparative material became available.

Today, phylogeny is resting on mtDNA sequencing and it would therefore be very important to analyze the holotypes of these species, if they were available. Ursus spelaeus (e.g., Hofreiter et al. 2004), Panthera leo spelaea (Burger et al. 2004) and Crocuta crocuta spelaea (Rohland et al. 2005) are being investigated already. Recently three of the holotype fossils were relocated: the tooth that 
was used by Blumenbach to establish Mammuthus primigenius at the University of Göttingen (Pressemitteilung 23.11.2005), the holotype cave lion skull at the Humboldt Museum and that of the cave hyena at the Goldfuß Museum, Bonn (Diedrich 2008). The Rosenmüller cave bear skull is, however, still missing or may have been lost during the World War II.

Old collections, like the one of the Natural History Museum, Berlin, i.e. the Museum of the Humboldt University (shortly termed Humboldt Museum hereafter), hold historic important specimens that may help in finding the missing specimen. In the public show room of the Museum the three valid "spelaeus-species" are shown side by side. The specimens are apparently from old collections. The Museum was therefore asked permission to look at these more closely and to take pictures. In addition, the authors were allowed to search the archive where much more material is stored. All specimens are noted with their modern archive numbers in a modern specimen book. Older documents seem to be missing. Thus only the specimens themselves and their original stickers may give answers as to their origin and provenience. Skulls and mandibles are measured after Tsoukala and Grandal d'Anglade (2002).

\section{THE CAVE BEAR SKULL ON DISPLAY}

The cave bear skull on display at the Humboldt Museum is a well preserved skull of a large, old individual (reg. No MB 48099, cranium 1, mandible 2; Fig. 2). Both mandibles displayed with it, are apparently not from the same animal since their molars form an angle when the lower jaw is fitted to the skull, thus the animal could not have chewed. Also there is about a $1 \mathrm{~cm}$ sideward gap between the molars of the lower jaw and those of the upper jaw.

The skull has a total length of $48 \mathrm{~cm}$ and a breadth at the zygomatical arches of $30 \mathrm{~cm}$. The breadth of the maxilla at the canines and between the $\mathrm{M} 2$ are $11.96 \mathrm{~cm}$ and $12.18 \mathrm{~cm}$, respectively, and the breadth minimum of the maxilla is $5.18 \mathrm{~cm}$. The teeth are well abraded and even the canines are mere stumps not allowing meaningful measurements. The following are still in situ: right: I3, C, P4, M1, M2 and left C, P4, M1, M2 (Fig. 3). The alveoli of the incisors are mostly closed; the animal lost these teeth during life.

The mandibles are 34 (right) and 35 (left) cm long. The maximum height is $21.5 \mathrm{~cm}$ (right) while the left processus coronoideus is damaged (19 cm high only). The breadth of the right processus condylaris is $7.64 \mathrm{~cm}$, the left processus is damaged. The mandibles are glued together at their symphysis. The following teeth are present: right $\mathrm{C}, \mathrm{m} 1, \mathrm{~m} 2, \mathrm{~m} 3$ and left $\mathrm{C}, \mathrm{m} 2, \mathrm{~m} 3$. The alveoli of both $\mathrm{p} 4$ are present. Table 1 gives some measurements of the lower teeth.

The skull is covered with a thin, black but rough flowstone veneer on top. The lower part is more brownish in color, illustrating that the skull was deposited in an upright position with the skull case rising above the sediment.

On the buccal side of the left mandible there is an old printed label saying "L'Herm (Ariége), Collection
Marty". Apparently both cranium and mandibles have been obtained from that collection together. The mammalian fauna of the cave of L'Herm in southern France was summarized in Clot and Duranthon (1990). No ref-

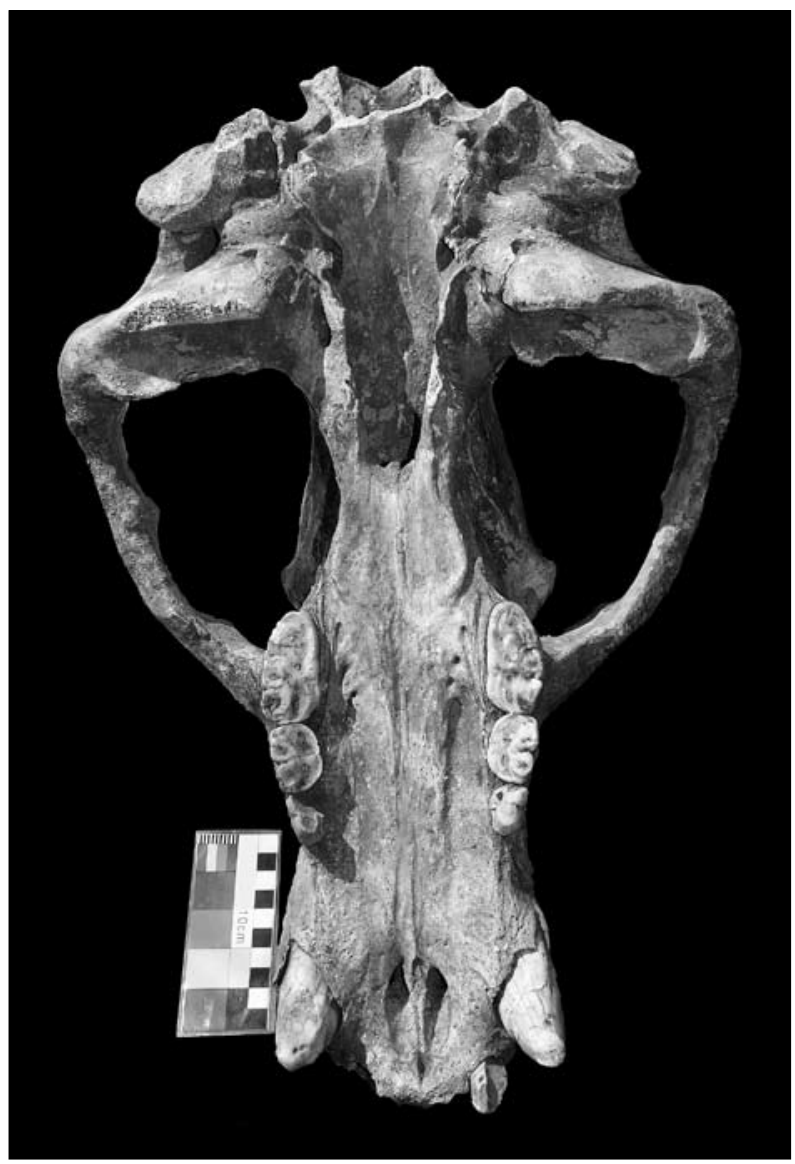

Fig. 3: Ventral view of the cave bear cranium from L'Herm (Ariége, France) (Photo: S. Kempe). 
Tab. 1: Ursus spelaeus; teeth measurements (in cm) from L'Herm (Humboldt Museum): Abbreviations: C - canine, $P$ - premolar, M/m - molar, L - length, B - breadth.

\begin{tabular}{|l|c|c|c|c|c|c|c|c|c|c|}
\hline maxilla & & & & & & & & & P4-M2 & C-M2 \\
\hline dex & & & & & & & & & 10.00 & 18.86 \\
\hline $\sin$ & & & & & & & & & 9.90 & 18.76 \\
\hline mandible & C-L & C-B & $\mathrm{m} 1-\mathrm{L}$ & $\mathrm{m} 1-\mathrm{B}$ & $\mathrm{m} 2-\mathrm{L}$ & $\mathrm{m} 2-\mathrm{B}$ & $\mathrm{m} 3-\mathrm{L}$ & $\mathrm{m} 3-\mathrm{B}$ & $\mathrm{m} 1-\mathrm{m} 3$ & $\mathrm{C}-\mathrm{m} 3$ \\
\hline $\operatorname{dex}$ & 3.53 & 2.56 & 3.24 & 1.68 & 3.37 & 2.13 & 2.96 & 2.05 & 9.4 & 21.75 \\
\hline $\sin$ & 3.35 & $2.05^{*}$ & & & 3.27 & 1.97 & 2.97 & 1.87 & $9.4^{*}$ & 21.40 \\
\hline
\end{tabular}

* damaged

erence to the collection Marty was found up to now. The sticker and the overall state of the skull suggest that the specimen has been a long time in the possession of the Humboldt Museum.

\section{THE CAVE LION SKULL ON DISPLAY}

The Humboldt Museum cave lion skull (MB 48115, cranium 1, mandible 2) in the public collection has been profusely treated with shellac (Fig. 4). The mandible displayed with it does not belong to the same individual. When fitting cranium and mandible together, there is a gap between both last molars of the upper and lower jaws of $1.6 \mathrm{~cm}$ (right) and $1.05 \mathrm{~cm}$ (left).

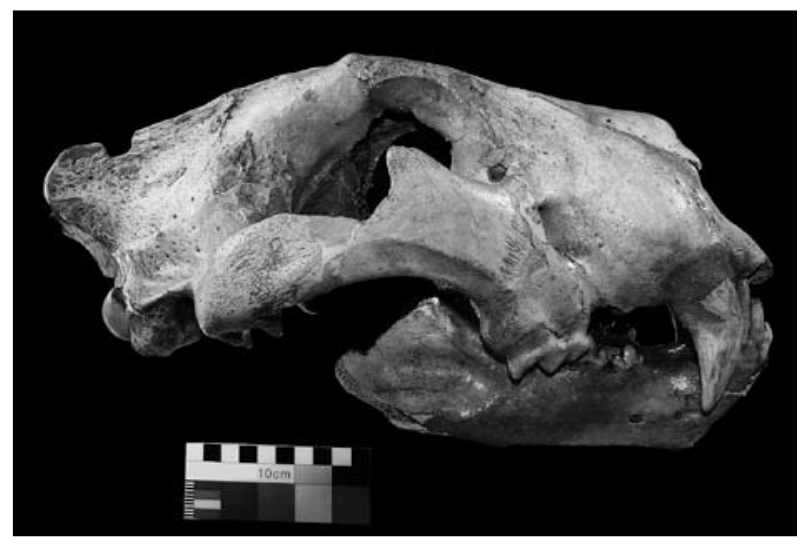

Fig. 4: Mounted cave lion skull from the Zoolithen Cave (Germany) of the original Rosenmüller collection (public collection at the Humboldt Museum) (Photo: S. Kempe).

Total length of the skull is $41.7 \mathrm{~cm}$. The breadth at the zygomatical arches can only be estimated because the left side is badly damaged. Measuring from the right zygomatical arch to the sagittal crest of the skull $(13.2 \mathrm{~cm})$ a breadth of $26.4 \mathrm{~cm}$ can be calculated. In the upper jaw only $\mathrm{C}$ and $\mathrm{P} 4$ are present. The $\mathrm{P} 4 \mathrm{~s}$ are heavily abraded lingually. The breadth of the maxilla at the canines is $11.6 \mathrm{~cm}$ and $14.75 \mathrm{~cm}$ for the breadth of the maxilla between the P4 (measurements of teeth see Tab. 2; Fig. 5).

Both mandibles are not very well preserved, the sections after the last molars are missing. Therefore no total length or maximum height can be given. The teeth (see Tab. 2 for measurements) are, however, well preserved:

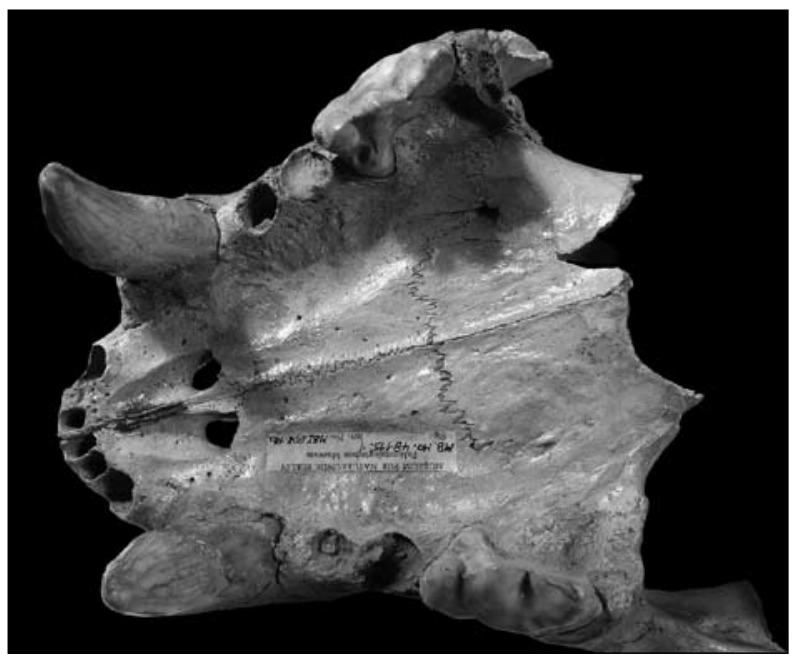

Fig. 5: Ventral view of the cave lion cranium from the Zoolithen Cave (Germany) (Photo: S. Kempe).

all are present apart from right I3. The canines are quite abraded.

Both the cranium and the mandibles carry printed stickers of the Humboldt Museum with handwritten archive numbers. In the current archive book they are 
Tab. 2: Panthera leo spelaea; teeth measurements (in $\mathrm{cm}$ ) from Zoolithen Cave (Humboldt Museum): Abbreviations: $C$ - canine, P/p - premolar, M/m - molar, L - length, B - breadth.

\begin{tabular}{|l|c|c|c|c|c|c|c|c|c|c|}
\hline maxilla & C-L & C-B & & & & & P4-L & $\begin{array}{c}\text { P4-B } \\
\text { (min) }\end{array}$ & C-M1 & \\
\hline dex & 3.40 & 2.40 & & & & & 4.17 & $2.14(1.63)$ & 12.10 & \\
\hline $\sin$ & 3.50 & 2.35 & & & & & 4.20 & $2.27(1.63)$ & 11.61 & \\
\hline mandible & & & p3-L & P3-B & p4-L & p4-B & m1-L & m1-B & C-m1 & p2-m1 \\
\hline $\operatorname{dex}$ & 2.27 & 1.79 & 1.82 & 1.06 & 2.56 & 1.33 & 2.92 & 1.49 & 13.40 & 7.57 \\
\hline $\sin$ & 2.66 & 1.86 & 1.40 & 1.08 & 2.65 & 1.29 & 3.02 & 1.58 & 13.49 & 7.84 \\
\hline
\end{tabular}

marked as "Panthera spelaea, Pleistocene, Gailenreuth". A handwritten label associated with one of the other three mounted skulls in the archive says (Fig. 6): "Felis spelaea Goldfuss, Schädel + UK [zweiter Schädel in Schausammlung] Jungquartär Gailenreuther Höhle, Franken, Coll. Rosenmüller, 118 Qu Kat. p. 64" (i.e. skull and mandible [second skull in the public collection] Upper Quaternary, Gailenreuther Cave, Franconia; collection Rosenmüller; 118 , Source Catalog p. 64). Thus the skull from the public collection is also from the original Rosenmüller collection. The word "Coll" is clearly spelled with a capital "C" suggesting that the noun "Collection" and not the verb "collected by" is meant by the abbreviation. Apparently this specimen carried the number 118 and was listed in the original catalog of the Museum on page 64. The skull with the label has a cranium and both mandibles and is the one identified now by Diedrich (2008) as the missing holotype. One of the other skulls has only a right mandible and one is mounted without mandibles.

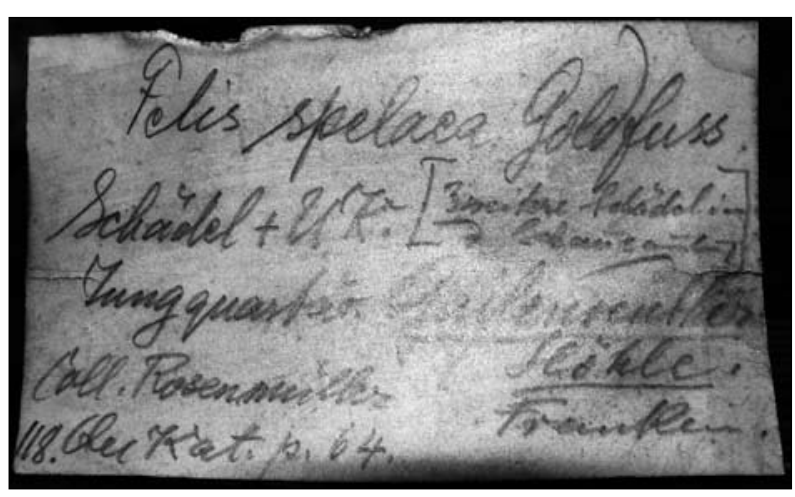

Fig. 6: Old museum label stating that the cave lion skull on display is from the Rosenmüller collection (Photo: S. Kempe).

\section{THE CAVE HYENA SKULL ON DISPLAY}

The third skull of a fossil animal from the Berlin collection bearing the species name "spelaeus/spelaea" on public display is that of the cave hyena (modern archive No. MB 48104; Fig. 7). Skull and both mandibles are not mounted on a plaster support like the two others but are placed side by side on the board. Again, mandibles and skull do not fit together and do not derive from the same individual. The skull shows substantial sinter cover over the palate, suggesting, that it was deposited upside down protruding from the sediment (Fig. 8).

The cranium is well preserved and has a total length of $30.8 \mathrm{~cm}$ and a breadth at the zygomatical arches of $20.02 \mathrm{~cm}$. The heights of the orbitae are 4.96 and $5.39 \mathrm{~cm}$ (right and left). The openings for the maxillary muscles measure (right) $8.5^{\star} 5.82 \mathrm{~cm}$ (length * width) and (left) $7.92^{\star} 6.8 \mathrm{~cm}$. The breadth of the condylii occipitales is $5.53 \mathrm{~cm}$. The breadth of the maxilla at the canines and between the P4s is 7.8 and 13.64 $\mathrm{cm}$, respectively, and the smallest breadth of the palate measures $4.05 \mathrm{~cm}$. Two of the incisors (I2, I3 left), both canines and all premolars are preserved in the skull (for measurements see Tab. 3; Fig. 8). The teeth show heavy signs of abrasion (the abrasion area of left P4 measures for example $3.23^{\star} 1.95 \mathrm{~cm}$ on the lingual side of the tooth crown.

The left mandible (Fig. 9) is about $11 \mathrm{~cm}$ high and $18.05 \mathrm{~cm}$ long. The right mandible is damaged and only $16.34 \mathrm{~cm}$ long. Both mandibles have been glued together at the symphysis. All the incisors are missing. Only two alveoli are still visible, indicating that the hyena lost them in vivo a long time before it died. The right canine is missing and the left one is splintered and somehow looks foreign and might be a later addition to the mandible. Otherwise the three premolars and the molars are well preserved, but show strong abrasion (measurements see Tab. 3). 


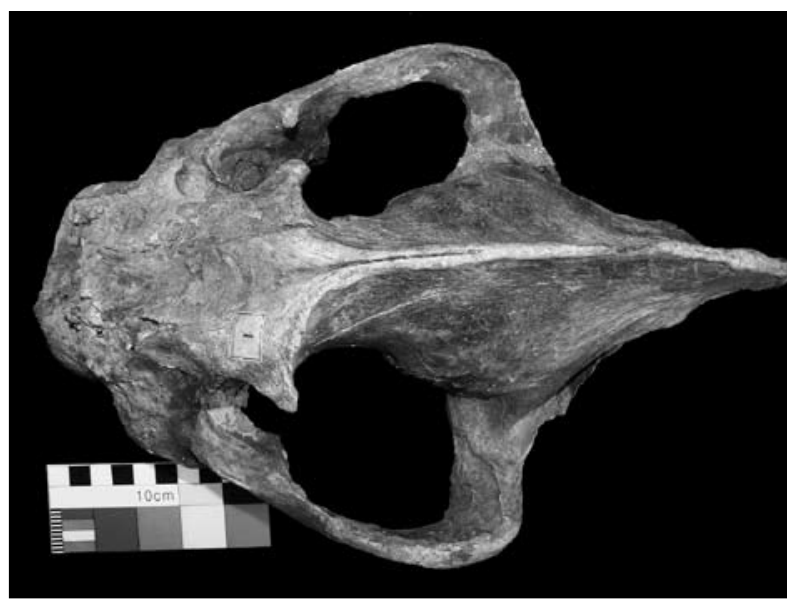

Fig. 7: Dorsal view of the cave hyena cranium from the Rösenbeck Cave (Germany) on display in the public collection (Photo: S. Kempe).

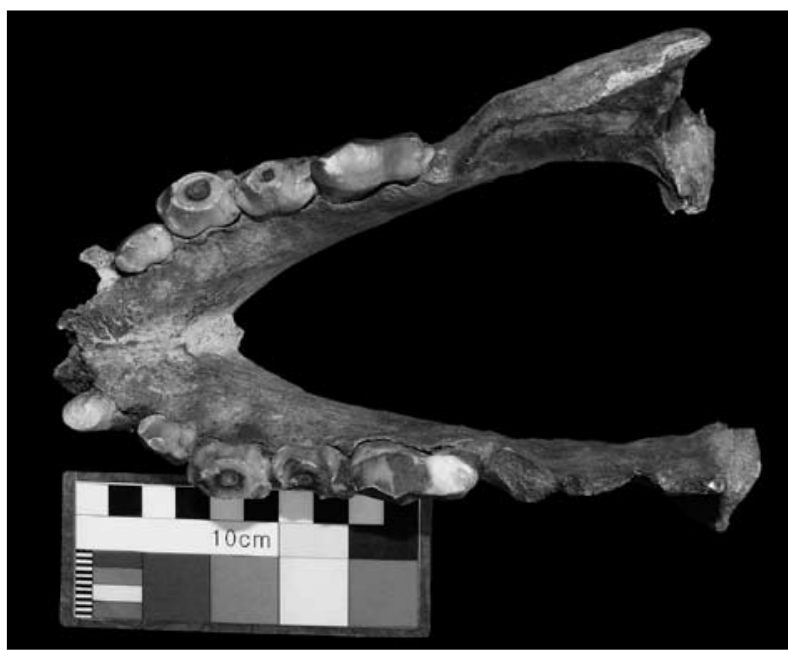

Fig. 9: Dorsal view of the mandibles of the cave hyena from Rösenbeck Cave (public collection) (Photo: S. Kempe).

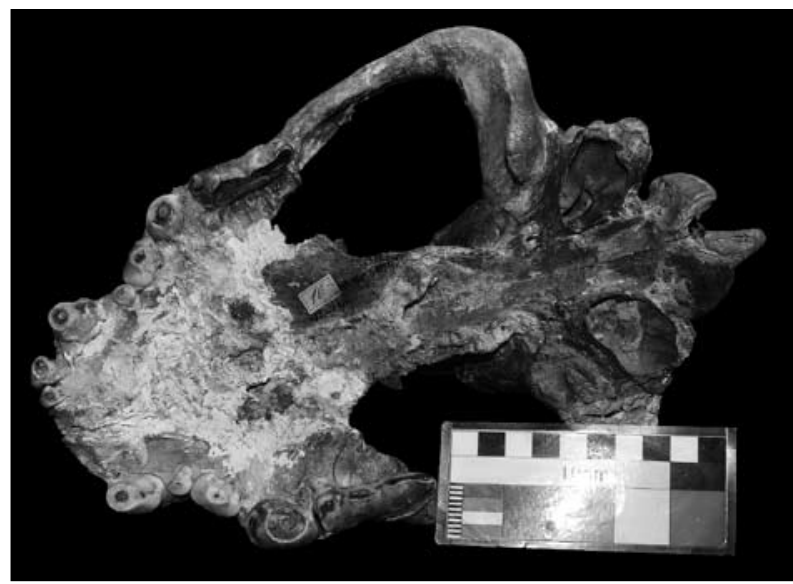

Fig. 8: Ventral view of the cave hyena cranium, note the flowstone cover of the palate (Photo: S. Kempe).

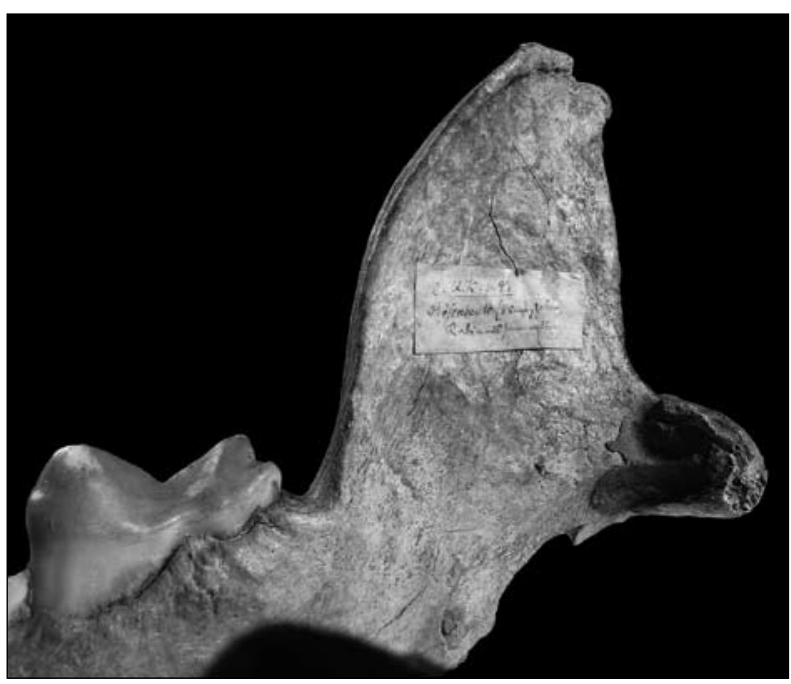

Fig. 10: Old provenience label on the inner side of the processus coronoideus of the cave hyena from the Rösenbeck Cave, Sauerland (Photo: S. Kempe).

Tab. 3: Crocuta crocuta spelaea; teeth measurements (in cm) from Rösenbeck Cave (Humboldt Museum): Abbreviations: C - canine, $P / p$ - premolar, $m$ - molar, L - length, B - breadth.

\begin{tabular}{|l|c|c|c|c|c|c|c|c|c|c|c|c|}
\hline maxilla & $C-L$ & $C-B$ & $P 1-L$ & $P 1-B$ & $P 2-L$ & $\begin{array}{c}P 2-B \\
(\max )\end{array}$ & $P 3-L$ & $\begin{array}{c}P 3-B \\
(\max )\end{array}$ & $P 4-L$ & $\begin{array}{c}P 4-B \\
(\min )\end{array}$ & $P 1-P 4$ & $P 3-P 4$ \\
\hline Dex & 1.87 & 1.35 & 0.78 & 0.83 & 1.77 & $\begin{array}{c}1.24 \\
(1.49)\end{array}$ & 2.28 & 1.32 & 4.35 & $\begin{array}{c}2.21 \\
(1.26)\end{array}$ & 9.11 & 6.62 \\
\hline Sin & 1.95 & 1.35 & 0.88 & 0.77 & 1.85 & $\begin{array}{c}1.23 \\
(1.35)\end{array}$ & 1.95 & $\begin{array}{c}1.23 \\
(1.34)\end{array}$ & 4.23 & $\begin{array}{c}2.13 \\
(1.36)\end{array}$ & 8.66 & 6.27 \\
\hline mandible & & & & & $P 2-L$ & $p 2-B$ & $p 3-L$ & $p 3-B$ & $p 4-L$ & $P 4-B$ & $m 1-L$ & $m 1-B$ \\
\hline Dex & & & & & 1.50 & 1.10 & 2.20 & 1.52 & 2.40 & 1.42 & 3.01 & 1.31 \\
\hline Sin & & & & & 1.42 & 1.09 & 2.18 & 1.51 & 2.33 & 1.41 & 3.10 & 1.30 \\
\hline
\end{tabular}

In addition to the modern archive number, there is a sticker on the inner side of the right mandible, very hard to read (Fig. 10): "2. UK p. 97 Rösenbeck ((1)810 ausgegraben (?)) Kabinetsammlung”; i.e. translated: 
"specimen two, lower jaw, p. 97 (probably of the mentioned older catalog) Rösenbeck 1810 excavated, cabinet collection". Thus the skull of the Berlin hyena is from
Rösenbeck Cave near Brilon, Sauerland, Germany. The site was described by Nöggerath in 1846 .

\section{ANOTHER ARCHIVED, MOUNTED CAVE BEAR SKULL FROM THE ROSENMÜLLER COLLECTION}

In the archived collection of the Humboldt Museum several other cave bear skulls exist; at least two have associated mandibles. One impressively large specimen is from the Heinrichshöhle near Hemer (Sundwig), Sauerland, Germany (Archive No MA 5018). Skull and mandibles are joined together by wires, so that exact measurement will have to wait (Fig. 11). In this case both parts seem to belong together.

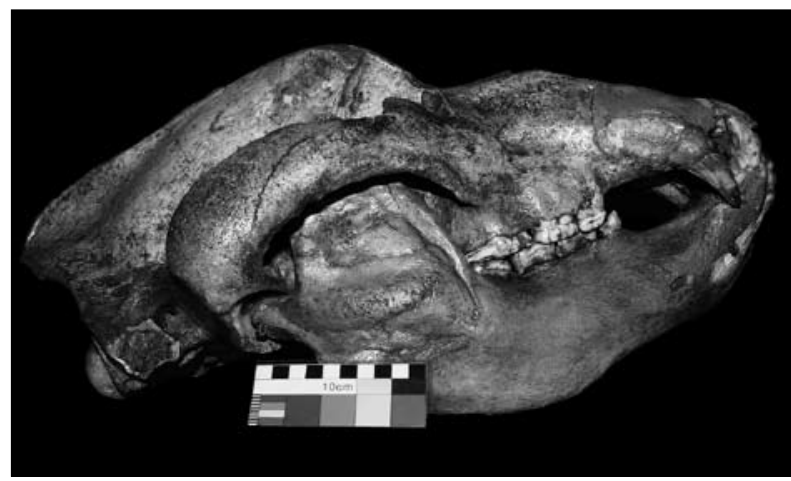

Fig. 11: Complete cave bear skull from the Heinrichshöhle near Hemer (Sundwig) from the archive of the Humboldt Museum (Photo: S. Kempe).

More intriguing was yet another cranium with both mandibles, mounted on plaster props just as the cave bear skull on display (MA 5017; Fig. 12). This one clearly is also from the Rosenmüller collection and therefore also of historical interest. Again, cranium and mandibles do not fit together. The mandibles are much darker in colour than the skull itself and show more abrasion.

The cranium is $41 \mathrm{~cm}$ long, the breadth at the $\mathrm{zy}$ gomatical arches is $24 \mathrm{~cm}$ and the breadth minimum of the maxilla is $4.49 \mathrm{~cm}$. The breadth of the condylii occipitales is $8 \mathrm{~cm}$ and the breadth of the foramen magnum measures $3.56 \mathrm{~cm}$. The teeth $\mathrm{C}, \mathrm{P} 4, \mathrm{M} 1$, and $\mathrm{M} 2$ are preserved on both sides. The breadth of the maxilla at the canines and of the maxilla between the M2 amounts to $10.3 \mathrm{~cm}$ and $10.75 \mathrm{~cm}$, respectively (Fig. 13). Tab. 4 gives teeth sizes and some of the distances.

Both mandibles were formerly joined together, but the glue has given away and the two mandibles separat- ed. The right mandible is $27.4 \mathrm{~cm}$ and the left one is 27.2 $\mathrm{cm}$ long, the processus coronoideus is missing. Both processi condylarii are slightly damaged (right $>5.5 \mathrm{~cm}$, left $>5.65 \mathrm{~cm}$ ). The following teeth are present: left: $\mathrm{C}, \mathrm{m} 1$, $\mathrm{m} 2, \mathrm{~m} 3$; right: $\mathrm{C}, \mathrm{p} 4, \mathrm{~m} 2$, and $\mathrm{m} 3$. The alveoli show that the missing teeth, also those of the incisors, were present

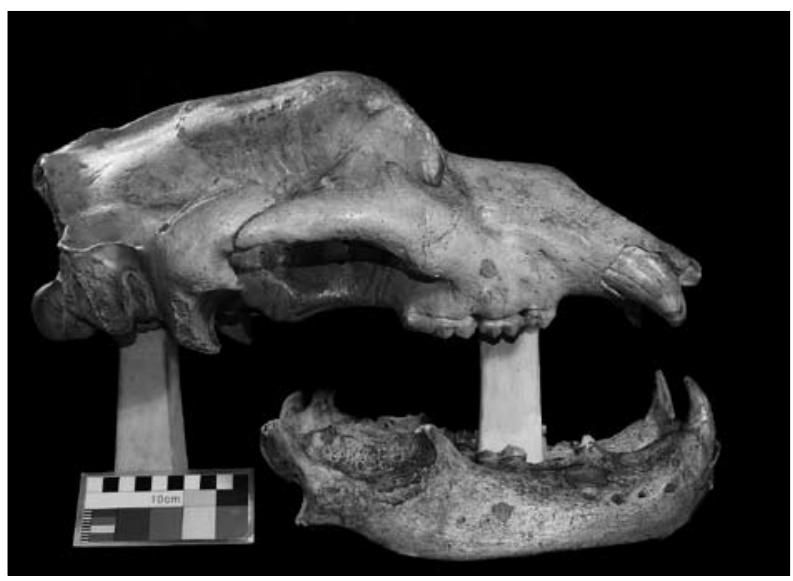

Fig. 12: Mounted cave bear cranium and mandible from the Zoolithen Cave originally from the Rosenmüller collection (archive of the Humboldt Museum) (Photo: S. Kempe).

in vivo. All teeth show medium abrasion. Teeth sizes are given in Tab. 4.

Both mandibles preserve the original stickers. The four-line label on the left jaw can still be read: " $82 \mathrm{UK}$ p. 63, Unterkiefer, Gaylenreuther Höhle, Coll. Rosenmüller", the first line on the sticker on the right jaw has faded entirely but the last two can be guessed to read as "Gaylenreuther Höhle, Coll. Rosenmüller”. The cranium also carries an old paper patch, that is faded entirely except for the three letters "Gay...", indicating that it also originates from the Zoolithen Cave at Gailenreuth. In more modern writing the archive number is added under the site specification "Gaylenreuther Höhle", most probably re-inking an older inscription because "Gaylenreuth" is a very oldfashioned way of spelling. In addition the mandible carries an inscription in black ink reading "Ursus spelaeus" (Fig. 14). Since the bones are from Rosenmüller's collection, the script may have been from his own hand. 


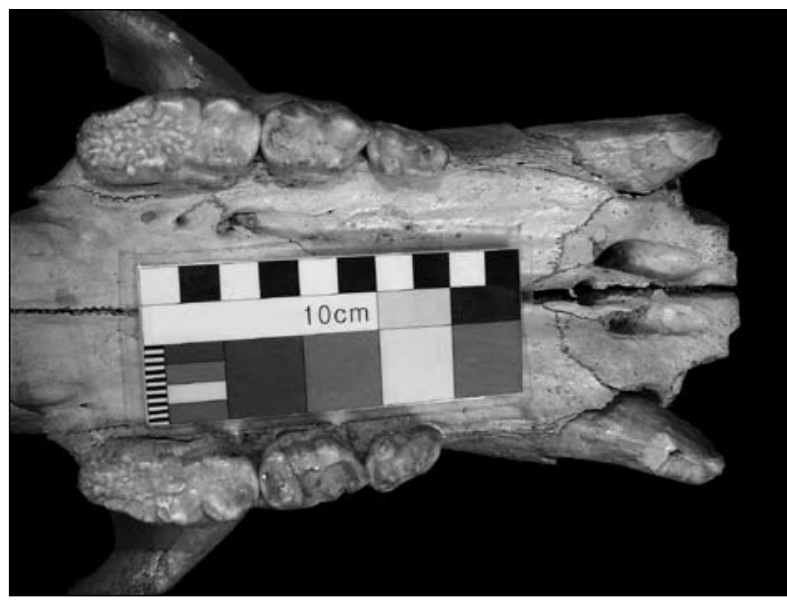

Fig. 13: Ventral view of the cave bear cranium from the Zoolithen Cave with the well preserved teeth (Photo: S. Kempe).

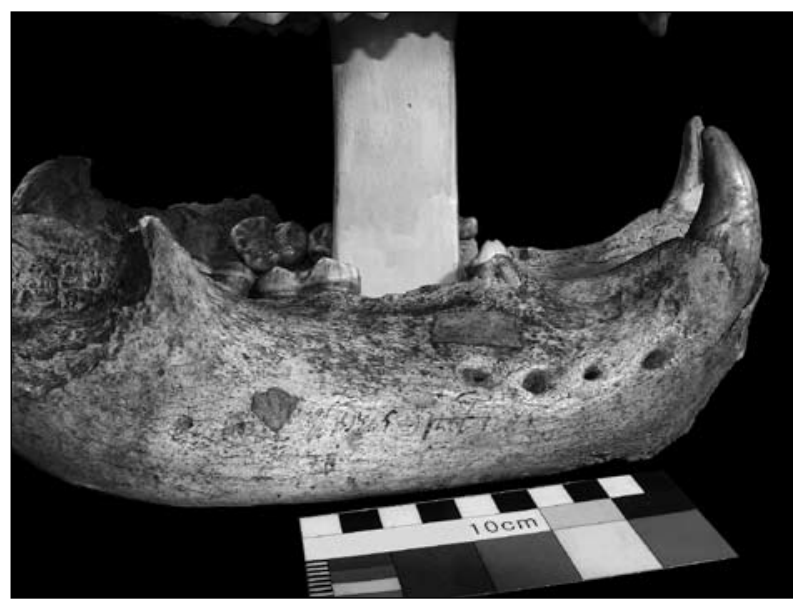

Fig. 14: Lateral view of the right mandible from the Zoolithen Cave with the faded old label and the ink inscription of "Ursus spelaeus" in old hand (Photo: S. Kempe).

Tab. 4: Ursus spelaeus; teeth measurements (in cm) from the Zoolithen Cave (Humboldt Museum): Abbreviations: C - canine, P/p - premolar, $M / m$ - molar, $L$ - length, $B$ - breadth, $d$-diastem (distance between canine and premolar).

\begin{tabular}{|c|c|c|c|c|c|c|c|c|c|c|c|c|c|}
\hline mandible & $C-L$ & $C-B$ & $P 4-L$ & $P 4-B$ & $m 1-L$ & $\begin{array}{l}m 1-B \\
(\max )\end{array}$ & $m 2-L$ & $\begin{array}{l}\operatorname{m2}-B \\
(\max )\end{array}$ & $m 3-L$ & $\begin{array}{l}\operatorname{m3-B} \\
(\max )\end{array}$ & $p 1-m 3$ & $C-m 3$ & $d$ \\
\hline Dex & 2.12 & 1.64 & 1.53 & 1.11 & & & 2.92 & $\begin{array}{c}1.80 \\
(2.01)\end{array}$ & 2.86 & $\begin{array}{c}1.87 \\
(2.20)\end{array}$ & 10.47 & 17.90 & 5.30 \\
\hline Sin & 2.32 & $\begin{array}{c}\text { ca. } \\
1.73\end{array}$ & & & 3.03 & $\begin{array}{l}1.22 \\
(1.7)\end{array}$ & 3.13 & $\begin{array}{c}1.73 \\
(1.85)\end{array}$ & 2.80 & $\begin{array}{c}1.93 \\
(2.15)\end{array}$ & 10.7 & 17.67 & ca. 4 \\
\hline maxilla & & & P4-L & $\begin{array}{l}\text { P4-B } \\
(\min )\end{array}$ & M1-L & $\begin{array}{l}\text { M1-B } \\
\text { (max) }\end{array}$ & M2-L & $\begin{array}{l}\text { M2-B } \\
(\min )\end{array}$ & & & $\begin{array}{l}\text { M1- } \\
\text { M2 }\end{array}$ & $C-M 2$ & \\
\hline Dex & 2.62 & 2.02 & 2.06 & $\begin{array}{c}1.42 \\
(1.13)\end{array}$ & 2.51 & $\begin{array}{c}1.84 \\
(1.86)\end{array}$ & 4.42 & $\begin{array}{c}2.10 \\
(1.85)\end{array}$ & & & 9.09 & 16.62 & 4.94 \\
\hline $\operatorname{Sin}$ & 2.63 & 2.04 & 2.07 & $\begin{array}{c}1.40 \\
(1.03)\end{array}$ & 2.52 & $\begin{array}{c}1.73 \\
(1.88)\end{array}$ & 4.44 & $\begin{array}{c}2.04 \\
(1.92)\end{array}$ & & & 9.12 & 16.77 & 4.33 \\
\hline
\end{tabular}

\section{THE “URSUS ARCTOIDEUS” SKULL}

In the archive another interesting bear skull (MA 2680) is stored (Fig. 15). It is $41.5 \mathrm{~cm}$ long and has a low forehead. The zygomatical arches are missing. The teeth show strong abrasion; C, P4, M1, M2 are present on both sides. In addition, the alveoli of $\mathrm{P} 1$ and $\mathrm{P} 3$ are present (Fig. 16). All incisors are missing, except of the root of the left I3.

The most interesting fact about this skull is the old three-line sticker reading: " 15 OK p. 58; Schädel des Ur- sus arctoideus; Blmb." i.e. the cranium of the species $U$. arctoideus that Blumenbach tried to establish as a separate species. The sticker does not reveal where the skull is from. Some of the circumstances associated with the $U$. arctoideus story are reported in Kempe et al. (2005). 


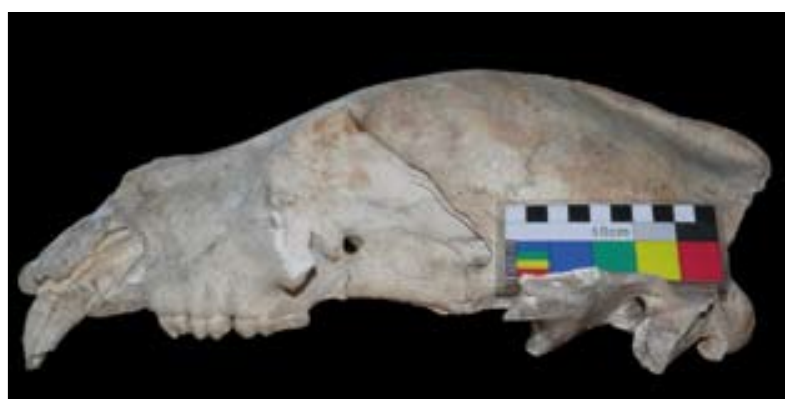

Fig. 15: Cave bear cranium of "Ursus arctoideus" from the archive of the Humboldt Museum. Note the relatively flat forehead (Photo: S. Kempe).

\section{THE “CANIS LUPUS SPELAEUS” SKULL}

Even more intriguing is the skull of a wolf (MA 2001; Fig. 17). It is mounted on plaster props, similar to those of the cave lions, and the separate old card board label with the printed line "Geol.-Paläont. Mus. Berlin" reads: "446. Qu Kat. p. 100 No 1. Canis lupus spelaeus Gf. Calvarium. Diluv. Gailenreuter Höhle Franken, Coll. Rosenmüller”. Thus the skull is also from the Rosenmüller collection and represents the Canis lupus spelaeus that Goldfuß (abbreviated here as Gf) tried to establish as a separate species in 1823 (Goldfuß 1823).

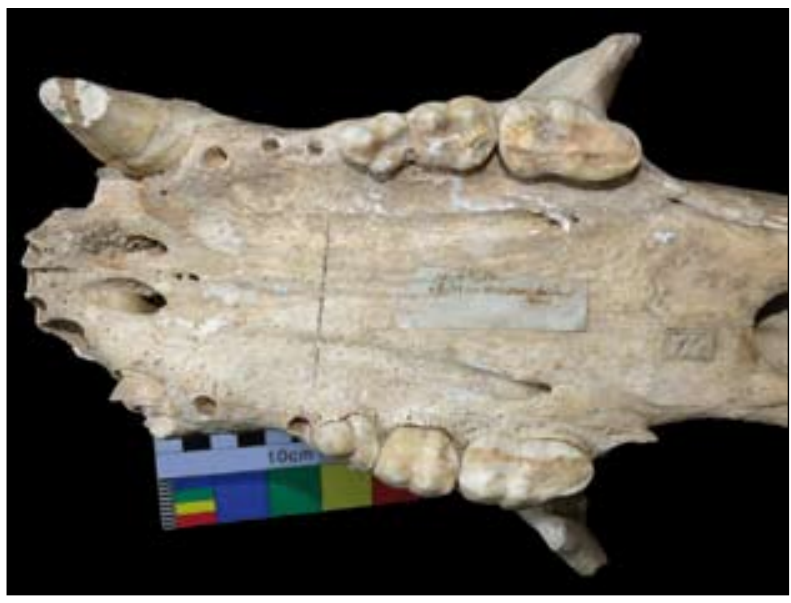

Fig. 16: Ventral view of the "Ursus arctoideus" with the alveoli of premolar 1 and 3. Note old label (Photo: S. Kempe).

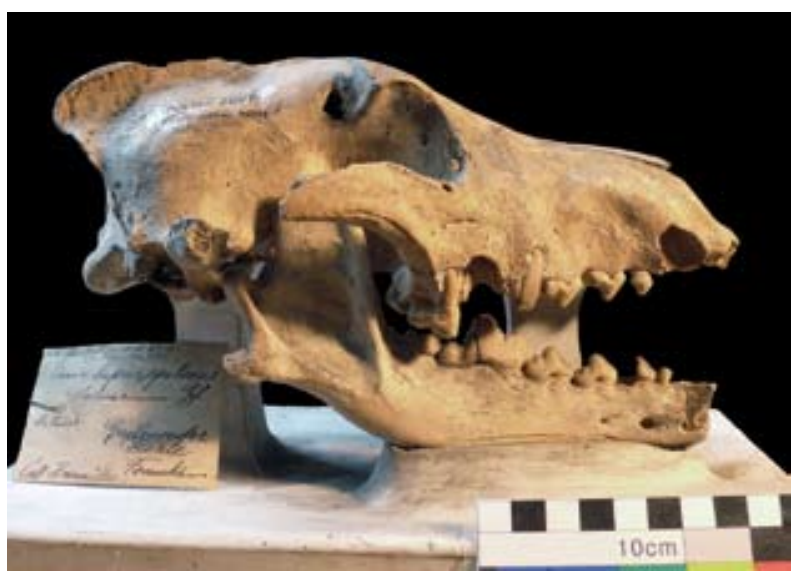

Fig. 17: Mounted skull of a wolf identified as "Canis lupus spelaeus, Goldfuß" from the Zoolithen Cave. Note separate old cardboard label identifying the specimen as derived from the Rosenmüller collection (Photo: S. Kempe).

\section{CONCLUSIONS}

This first, and admittedly superficial inspection of the "spelaeus species" (Ursus, Crocuta, Panthera, Lupus) stored at the Humboldt Museum in Berlin showed that several fossils are from Rosenmüller's original collection. It is known that his collection has been scattered widely. Specimens are, for example, known to us from the collections in the museums and institutes of Erlangen, Bonn, Bayreuth, Monaco, Bottrop, Bamberg, London, and Paris. Two card board labels and several old stickers identify at least four of the Berlin fossils as derived from this famous collection. They also mention a catalog abbreviated as "Qu Kat", i.e. a "Quell-Katalog" or source catalogue, that was kept by the Museum and that carried information as to the provenience of the pieces and that is either lost or currently unavailable.

At least one of the complete cave bear skulls in the archive is from Rosenmüller's Zoolithen Cave collection. When compared (Fig. 12) to the original copperplate (Fig. 1) it is clearly not the holotype. The skull in the public collection that at first view is very similar to Rosenmüller's skull (in as much as it has much abraded molars) originates from L'Herm in France and therefore cannot be the holotype either. 
At least two of the cave lion skulls originated from the Rosenmüller collection (and possibly all four of them) as well. It is known from the literature (Goldfuß 1810 , footnote page 278) that Rosenmüller was planning to publish a paper about the cave lion. Therefore the cave lion skulls in the Berlin collection might be those specimens that Rosenmüller wanted to use for the description of the cave lion. Rosenmüller never finished this publication and, in 1810, Goldfuß named the cave lion "Felis spelaea" without actually describing it in detail, apparently not wanting to interfere with Rosenmüller's plans. When comparing the Goldfuß picture of the cave lion skull with the skull in the public collection, it appears that it is missing the incisors while the Goldfußholotype clearly has incisors present in the cranium. One of the other skulls may, according to Diedrich (2008), be the missing holotype, even though the comparison of it with the copper plate leaves a certain amount of doubt about this parallelization.

The cave hyena skull on display is from the Rösenbeck Cave, Sauerland, and therefore also not identical with the skull that Goldfuß used to establish the cave hyena as a separate species in 1823 . Nevertheless, this is a very interesting observation because Nöggerath (1846) described the Rösenbeck Cave as a typical hyena den cave that delivered several well preserved hyena skulls. First opened by road work, it was excavated in 1830 more thoroughly according to Nöggerath's notes. So far none of these skulls seems to have been published in detail. If the reading on the label with (1)810 is correct, the skull would be one of the first ones to have been taken from the cave, a fact in accordance with the flowstone cover on the palate, suggesting that it was partly exposed above the sediment.

Most intriguing is the complete skull of a wolf in the archive. This specimen is also from Rosenmüller's Collection from the Zoolithen Cave and may be a missing holotype; however, of a species that never was accepted as such.

Very interesting is also the "arctoideus" skull in the Humboldt Museum Archive. Due to the fact that it displays alveoles of the P1 and P3, it might turn out to be a fossil Ursus arctos skull.

Overall, we still can learn a lot by the inspection of archived vertebrate fossils, specifically when the old labels reveal their provenience. The specimens from the Zoolithen Cave and from the Rösenbeck Cave at the Humboldt Museum in Berlin merit further attention and certainly should be included in future DNA studies.

\section{ACKNOWLEDGEMENTS}

The authors thank Dr. Jürgen Kriwet (fishes), Dr. WolfDieter Heinrich (mammals) and the staff of the Museum for Natural Sciences of the Humboldt University, Berlin, for permission to take pictures and measurements of specimens from the public collection and archive. We also want to thank Dr. Irena Debeljak (Scientific Research Centre of the Slovenian Academy of Sciences and Arts) for critical comments.

\section{REFERENCES}

Blumenbach, F., 1799: Handbuch der Naturgeschichte, 6. Ausg.- Joh. Chr. Dieterich, pp. 708, pp. 34 index, 2 copperplates, Göttingen.

Burger, J., Rosendahl, W., Loreille, O., Hemmer, H., Eriksson, T., Götherström, A., Hiller, J., Collins, M.J., Wess, T. \& K.W. Alt, 2004: Molecular phylogeny of the cave lion Panthera leo spelaea.- Molecular Phylogenetics and Evolution, 30, 841-849.

Clot, A. \& F. Duranthon, 1990: Les mammifères fossiles $d u$ Quaternaire dans les Pyrénées.- Mus. d'Hist. nat., pp. 153, Toulouse.
Diedrich, C.G., 2008: The holotypes of the upper Pleistocene Crocuta crocuta spelaea (Goldfuss, 1823: Hyaenidae) and Panthera leo spelaea (Goldfuss, 1810: Felidae) of the Zoolithen Cave hyena den (South Germany) and their palaeo-ecological interpretation.- Zool. J. Linnean Soc., 154, 822-831.

Erdbrink, D.P., 1953: A Review of Fossil and Recent Bears of the Old World; with Remarks on their Phylogeny, Based upon their Dentition, 2 Vol.- Jan de Lange, pp. 597, pp. 12 index, plates, Deventer. 
Esper, J.F., 1774: Ausführliche Nachricht von neuentdeckten Zoolithen unbekannter vierfüssiger Thiere, und denen sie enthaltenden, so wie verschiedenen andern denkwürdigen Grüften der Obergebürgischen Lande des Marggrafthums Bayreuth.- Georg Wolfgang Knorrs seel. Erben, pp. 148, 14 copperplates, Nürnberg.

Goldfuß, G.A., 1810: Die Umgebung von Muggendorf, ein Taschenbuch für Freunde der Natur- und Alterthumskunde.- Johan Jacob Palm, pp. 352, 6 copperplates, 1 map, Erlangen.

Goldfuß, G.A., 1818: Beschreibung eines fossilen Vielfrass-Schädels aus der Gailenreuther Höle.- Nov. Act. acad. Leopold., IX, 313-322.

Goldfuß, G.A., 1823: Osteologische Beiträge zur Kenntniß verschiedener Säugethiere der Vorwelt. V. Ueber den Hölenwolf (Canis spelaeus).- Nov. Act. acad. Leopold., XI, 451-455.

Hofreiter, M., Rabeder, G., Jaenicke-Després, V., Withalm, G., Nagel, D., Paunovic, M., Jambrěsic, G. \& S. Pääbo, 2004: Evidence for reproductive isolation between cave bear populations.- Current Biol., 14, 40-43.

Horst, J.D., 1656: Observationum Anatomicarum Decas.W. Serlinus \& G. Fickwirth, pp. 34, Frankfurt.

Kempe, S., Rosendahl, W. \& D. Döppes, 2005: The making of the cave bear - Die wissenschaftliche Entdeckung des Ursus spelaeus.- Festschrift G. Rabeder Mitt. Komm. Quartärforsch. Österr. Akad. Wiss., 14, 5773.

Kempe, S., Fricke, U., Kleinschmidt, A. \& F. Reinboth, 1999: Die Baumannshöhle, Harz, ihre Bedeutung für die frühe Wissenschaftsgeschichte, ihre Darstellung durch Johann Friedrich Zückert, der Arzneygelahrtheit Doctor, 1763, und was heute noch davon zu sehen ist.- Abhandlungen Verband Dt. Höhlen- $\mathrm{u}$. Karstforsch. Reihe A-F (31), pp. 55 + pp. XXVI.

Linné, C. von, 1758: Systema naturae per regna tria naturae, secundum classes, ordines, genera, species, cum characteribus differentiis, synonymis, locis (10. ed.).

Nielbock, R., 2004: Wie das Einhorn „erfunden“ wurde.Unser Harz, Z. f. Heimatkunde, Brauchtum und Natur 52. Jg. 2/04, 23-24, Clausthal-Zellerfeld.

Nöggerath, J., 1846: Über einige Knochen führende Höhlen in dem großen rheinisch-westphälischem Kalkzug.- Neues Archiv für Mineralogie, Geologie, Bergbau und Hüttenkunde, XX, 328-350.
Paterson Hain, J., 1673a: Observatio CXXXIX, de Draconibus Carpathicis.- Miscellanea Curiosa Medico-Physica Academiae Naturae Curiosorum, sive Ephemeridum Medico-Physicarium Germanicarum; Sumptibus Haeredum Schnureri Gözianorum \& Johannis Fritzschii, Typin Johann Georgii Drulmanni, pp. 616, index (pp. 257-259, 1 folded copperplate), Lipsiae \& Francofurti. (Note: the same paper was possibly published a year earlier in the French edition of the magazine: Paterson Hayn, J., 1672: Éphémérides des curieux de la nature, dec. I, an. III, obs CXXXIX, S. 220.)

Paterson Hain, J., 1673b: Observatio CXCIV, de Draconum Carpathiicorum Cavernis.- Miscellanea $\mathrm{Cu}$ riosa Medico-Physica Academiae Naturae Curiosorum, sive Ephemeridum Medico-Physicarium Germanicarum; Sumptibus Haeredum Schnureri Gözianorum \& Johannis Fritzschii, Typin Johann Georgii Drulmanni, pp. 616. pp. 31 index, (pp. 366370, 1 copperplate), Lipsiae \& Francofurti.

Pressemitteilung 23.11.2005: http://www.geobiologie. uni-goettingen.de/museum/presse_mammut2.pdf.

Rohland, N., Pollack J.L., Nagel, D., Beauval, C., Airvaux, J., Pääbo, S. \& M. Hofreiter, 2005: The population history of extant and extinct hyenas.- Molecular Biology and Evolution, 22(12), 2435-2443.

Rosendahl, W. \& S. Kempe, 2004: Johann Christian Rosenmüller und der Höhlenbär (1794-2004) "Lebensbilder" aus 210 Jahren.- Natur und Mensch, Naturhistorische Gesellschaft Nürnberg e.V., Jahresmitteilungen 2003, 145-159.

Rosenmüller, J.C., 1794: Quaedam de ossibus fossilibus animalis cujusdam, historiam ejus et cognitionem accuratiorem illustrantia, disertatio, quam d, 22. Octob. 1794. Ad disputandum proposuit Ioannes Christ. Rosenmüller Heßberga-Francus, LL. AA. M. in Theatro anatomico Lipsiensi Prosector assumto socio Io. Chrs. Heinroth Lips. Med. Stud. cum tabula aenea.pp. 34., 1 copperplate, Leipzig.

Rosenmüller, J.C., 1795: Beiträge zur Geschichte und nähern Kenntniß fossiler Knochen.- Georg Emil Beer, pp. 92, 1 unpag. p., 1 copperplate, Leipzig.

Rosenmüller, J.C., 1804: Abbildungen und Beschreibungen der fossilen Knochen des Höhlenbären. Description des os fossiles de l'Ours des Cavernes avec figures.Verlag d. F. S. Privil. Landes-Industrie-Comptoirs, IV, pp. 22, 8 copperplates, Weimar.

Tsoukala, E. \& A. Grandal d'Anglade, 2002: Système de mesures du squelette des Ursidés.- Études et Recherches Archéologiques de l'Université de Liège (ERAUL) 100, 265-287. 
Vladi, F., 1979: Die Nashornfunde zu Düna (NSG Hainholz) vom Jahre 1751 - und ihre Bedeutung für „die physische Geschichte unseres Planeten".- Heimatblätter für den südwestlichen Harzrand, H. 35, 3945, 5 Abb., Osterode am Harz.

Vollgnad, H., 1676: Observatio CLXX. De Draconibus Carpathicis et Transsylvanicis. - Miscellanea Curiosa Medico-Physica Academiae Naturae Curiosorum, sive Ephemeridum Medico-Physicarium Germanicarum.- Sumptibus Johannis Fritzschii, Bibliopolae Lipsiensis, pp. 315 (pp. 226-229, 1 folded copperplate), Francofurti \& Lipsiae.
Zückert, J.F., 1763: Die Naturgeschichte einiger Provinzen des Unterharzes nebst einem Anhange von den Mannsfeldischen Kupferschiefern.- Friedrich Nicolai, pp. 212, Berlin. 